\title{
SOUTHERN AFRICAN GEOMORPHOLOGY: LOOKING BACK, MOVING FORWARD
}

\author{
PAUL D. SUMNER ${ }^{1}$, WERNER NEL ${ }^{2}$, PETER J. HOLMES ${ }^{3}$ AND MARY SEELY ${ }^{4}$ \\ ${ }^{1}$ Department of Geography, Geoinformatics and Meteorology, University of Pretoria, Hatfield, South Africa \\ ${ }^{2}$ Department of Geography and Environmental Science, University of Fort Hare, Alice, South Africa \\ ${ }^{3}$ Department of Geography, University of the Free State, Bloemfontein, South Africa \\ ${ }^{4}$ Gobabeb Research and Training Centre, Walvis Bay, Namibia
}

Geomorphology in southern Africa has evolved into a unique, distinct and recognised discipline within the earth science context. Since its inaugural meeting in 1988, the Southern African Association of Geomorphologists (SAAG) has comprised of a relatively small but dynamic academic community convening biennial conferences at locations across the sub-continent. It is undoubtedly fitting that the venue for the most recent (2012) conference of SAAG was the Gobabeb Research and Training Centre in the Namibian Desert. The Centre has a long standing reputation for facilitating research excellence (see Henschel and Lancaster 2013) and it was at this conference that the proposal for this special issue was presented. While the theme of the conference was 'Celebrating 50 years of Namib Desert Research' the program was by no means limited to papers on arid geomorphology. Southern African geomorphological research has always been diverse in nature but, whatever the specific context of geomorphic research, the broader (regional) context is one of dryness. The conference also served as a platform for the launch of a new book entitled Southern African Geomorphology; Recent Trends and New Directions, edited by Peter Holmes and Michael Meadows (Holmes and Meadows 2012). This is the first new, comprehensive title devoted to southern African geomorphology since the publication, 25 years ago, of Bernie Moon and George Dardis' edited volume on The Geomorphology of Southern Africa (Moon and Dardis 1988). Both books serve as definitive texts on the state of southern African geomorphology and its contribution within the global arena.

Over the past two decades, the 'internationalisation' of geomorphic research in southern Africa has been facilitated by the political developments of the early nineties that saw the end of academic boycotts and greater interest in conferences hosted within the region. This period has been characterised by a phenomenal increase in collaborations between southern African geomorphologists and colleagues from international institutions, particularly those based in the United Kingdom, but also in Europe and America. In Holmes and Meadows (2012), 11 of the 24 contributing authors, and no fewer than eight of the 13 referees are scientists based outside of southern Africa. At the Gobabeb gathering, approximately half of the 35 oral and 18 poster presentations were authored or co-authored by foreign delegates. Of the 53 delegates who presented, 19 were emerging researchers and the Oxford group's training programme brought emerging geomorphologists together on the Namib dunes to learn more about ground-penetrating radar and its application. Outside of the arid theme, Southern African geomorphologists and their co-workers embrace a number of diverse topics including weathering, cold climates and climate change, hydro-geomorphology, coastal and karst geomorphology and degradation (see Beckedahl et al. 2002). With the research heritage of Gobabeb presented elsewhere (Henschel 
and Lancaster 2013), this special edition portrays the ongoing geomorphological research in its broader sense. It mostly constitutes papers presented at Gobabeb and represents the eclectic range of geomorphological topics which reflects the diverse nature of southern African geomorphological research.

For this issue, some authors chose a critical review approach as their focus while other papers present primary data and interpretation from the field and laboratory. Eckardt et al. (2013) provide an overview of the surface geology and geomorphology around Gobabeb in the Central Namib Desert. The paper introduces the major lithologies associated with the Damara Orogen of Precambrian and Cambrian age, followed by Tertiary sandstones and conglomerates and Quaternary Kuiseb valley conglomerates, silts and gravels. To commemorate the 50th anniversary of the Gobabeb research station and to pay tribute to the recent designation of the Namib Sand Sea as a world heritage site, Eckardt et al. (2013) also present a map to inform and guide future research and educational activities around Gobabeb.

Boelhouwers and Jonsson (2013) assess the temporal threshold for thermal shock weathering. This discussion paper questions the role of thermal shock weathering in cold regions and places renewed emphasis on the importance of absolute temperature and measurement of strain, as well as spatial temperature gradients. In a laboratory study, Loubser (2013) applies wetting and drying cycles to sandstone and basalt from South Africa and Marion Island respectively. Small changes in internal rock structure are noted to have an effect on the nature of weathering and the number of wetting and drying cycles is found to be more important than the degree to which saturation occurs. In Antarctica, Hansen et al. (2013) show that aspect exerts a control on weathering of blocks in a blockfield in Dronning Maud Land. The authors argue that a higher radiation budget associated with slope aspect and angle could drive thermal regimes and subsequent weathering of clast faces. In the absence of abundant precipitation, ice and snow become the moisture source in this high latitude Antarctic environment.

Hedding and Sumner (2013) review and refine the diagnostic criteria for pronival ramparts. Their paper emanates in part from some of the controversial relict features in southern Africa and collates rampart characteristics from active field sites near the South African research bases in the sub- and continental Antarctic, amongst others. Le Roux and Sumner (2013) draw from several multi-scale studies on soil erosion in South Africa and propose a methodological framework for water erosion risk assessment. Three hierarchical levels are presented that range from a small catchment to a national scale. While the assessment levels broadly match those proposed elsewhere in the globe, the framework emphasises the most feasible erosion assessment techniques and input datasets for a developing country where data are inherently more limited. Nel et al. (2013) assess the temporal attributes of rainfall and compare two commonly used erosivity indexes on the tropical island of Mauritius. For the computation of erosivity, the authors find that rainfall data with the highest possible resolution should be utilised and that the application of annual and monthly rainfall totals to assess absolute soil erosion risk within such an environment should be used cautiously.

Reinwarth et al. (2013) present a 700-year record on the effects of climate and human impact on the southern Cape coast inferred from lake sediments. The data show that changes in the seasonal distribution of rainfall during the Little Ice Age may have altered river discharge and increased erosion rates and fluvial sediment transport in pre-colonial times. Enhanced sedimentation rates, increasing carbon, nitrogen, phosphorous and biogenic silica concentrations, 
as well as high concentrations of proxies for allochthonous sediment input point to increasing sediment and nutrient flux into Eilandvlei from the late nineteenth century onwards. It is suggested that the most likely factor involved in these recent changes is land-use change and other forms of human impact. This special issue also includes a paper by friends and colleagues of the late Helga Besler (Besler et al. 2013). As a tribute to her life and work at Gobabeb, 40 years of data on dynamics are presented on what fondly is known as Helga's Dune. The data show changes in dune behavior that appear to be related to changes in wind regime and vegetation cover of the interdune area as a result of increased rainfall in recent years. The study demonstrates the dynamic nature of the dune tip and its sensitivity to changes in wind and sand supply.

Southern African geomorphological research has increased exponentially over the last two decades. This is reflected in recent titles (Holmes and Meadows 2012), the volume and quality of research published in local and international journals, the number of collaborative projects between South Africans and their colleagues abroad and the increasing proportion of foreign membership of SAAG. This issue represents a cross-section of work being undertaken by South Africans and their collaborators and substantiates our confident assertion that academic geomorphology in our country is diverse, alive and well. The international interest in southern Africa is demonstrated in the author profiles but of equal or possibly greater significance for the future are the number of contributors who are emerging researchers in the discipline. We trust that, from this foundation, local and international interest in the geomorphology of the subcontinent will continue to thrive into the future.

\section{Acknowledgements}

We wish to thank all the contributing authors for their efforts in ensuring quality papers and the reviewers who's time and efforts under stringent deadlines have significantly helped to improve the papers. We are grateful for the opportunity to collectively publish the work of southern African geomorphologists in a thematic issue of Geografiska Annaler: Series A, Physical Geography and a special thank you is extended to the editors-in-chief Jan Boelhouwers, for sowing the seed of this issue at the Gobabeb conference, and Peter Jansson and for his dedicated and professional assistance in guiding us through the process.

\section{Biographies}

Paul D Sumner, Department of Geography, Geoinformatics and Meteorology, University of Pretoria, Private Bag X20, Hatfield, 0028, South Africa

E-mail: paul.sumner@up.ac.za

Werner Nel, Department of Geography and Environmental Science, University of Fort Hare, Private Bag X1314, Alice, 5700, South Africa

E-mail: WNel@ufh.ac.za 
Peter J Holmes, Department of Geography, University of the Free State, PO Box 339, Bloemfontein, 9300, South Africa,

E-mail: holmespi@ufs.ac.za

Mary Seely, Gobabeb Research and Training Centre, P O Box 953, Walvis Bay, Namibia

E-mail: Mary.Seely@drfn.org.na

\section{References}

Beckedahl, H.R., Sumner P.D. and Garland, G. 2002. Southern African geomorphology: critical choices for the future. South African Geographical Journal, 84, 145-152.

Besler, H., Lancaster, N., Bristow, C., Henschel, J., Livingstone, I., Seely, M. and White, K. 2013. Helga's Dune: 40 years of dune dynamics in the Namib Desert. Geografiska Annaler: Series A, Physical Geography, 95, 285-293, doi: 10.1111/geoa.12013

Boelhouwers, J.C. and Jonsson, M. 2013. Critical assessment of the $2^{\circ} \mathrm{C} \min ^{-1}$ threshold for thermal stress weathering Geografiska Annaler: Series A, Physical Geography, 95, 285-293. doi: $10.1111 /$ geoa.12026

Eckardt, F.D, Livingstone, I. and Seely, M., Von Holdt, J.R.C 20xx. An introduction to the surface geology and geomorphology around Gobabeb, Namib Desert, Namibia. Geografiska Annaler: Series A, Physical Geography, 95, 271-284, doi: 10.1111/geoa.12028

Hansen, C.D., Meiklejohn, K.I., Nel, W., Loubser, M.J. and Van der Merwe, B.J. 2013. Aspectcontrolled weathering observed on a blockfield in Dronning Maud Land, AnGeografiska Annaler: Series A, Physical Geography, 95, 305-313, doi: 10.1111/geoa.12025

Hedding, D.W. and Sumner, P.D. 2013. Diagnostic criteria for pronival ramparts: site, morphological and sedimentological characteristics. Geografiska Annaler: Series A, Physical Geography, 95, 315-322. doi: 10.1111/geoa.12021

Henschel, J.R. and Lancaster, N. 2013. Gobabeb - 50 years of Namib Desert research. Journal of Arid Environments, 93, 1-6.

Holmes P.J. and Meadows M.E. 2012. Southern African Geomorphology; Recent Trends and New Directions. Sun, Bloemfontein.

Le Roux, J.J. and Sumner, P.D. 2013. Water erosion risk assessment in South Africa: a proposed methodological framework. Geografiska Annaler: Series A, Physical Geography, 95, 323336, doi: 10.1111/geoa.12018

Loubser, M.J. 2013. Wetting and drying weathering of basalt and sandstone: a process isolation study. Geografiska Annaler: Series A,Physical Geography, 95, 295-304, doi: 10.1111/geoa. 12023 
Moon, B.P. and Dardis, G.F. 1988. The Geomorphology of Southern Africa. Southern, Johannesburg.

Nel, W., Anderson, R.L., Sumner, P.D., Boojhawon, R., Rughooputh, S.D.D.V. and Dunputh, B.H.J., 2013. Temporal sensitivity analysis of erosivity estimations in a high rainfall tropical island environment. Geografiska Annaler: Series A,Physical Geography, 95, 337-343 , doi:10.1111/geoa.12017

Reinwarth, B., Franz, S., Baade, J., Haberzettl, T., Kasper, T., Daut, G., Helmschrot, J., Kirsten, K. L., Quick, L. J., Meadows, M. E. and Mäusbacher, R. 2013. A 700-year record on the effects of climate and human impact on the southern Cape coast inferred from lake sediments of Eilandvlei, Wilderness Embayment, South Africa. Geografiska Annaler: Series A, Physical Geography, 95, 345-360, doi: 10.1111/geoa.12015 